\title{
PENGARUH RISEDRONATE BISPHOSPHONATE TERHADAP ENZIM TRAP (EKSPRESI OSTEOKLAS) DI SEKITAR SUBSTRUKTUR IMPLAN GIGI ENDOSSEOUS
}

\author{
(EFFECT OF RISEDRONATE BISPHOSPHONATE ON ENZYM TRAP \\ (OSTEOCLAST EXPRESSION) SURROUNDINGS SUBSTRUCTURE \\ ENDOSSEOUS DENTAL IMPLANT)
}

\author{
Suparyono Saleh*, Iwan Dwi Prahasto**, Munakhir Mudjosemedi***, Ika Dewi Ana**** \\ *Departemen Prostodonsia \\ **Departemen Farmakologi dan Toksikologi \\ Fakultas Kedokteran, Universitas Gajah Mada \\ ***Departemen Radiologi Dentomaksilofasial \\ ****Departemen Biomedika Kedokteran Gigi \\ Fakultas Kedokteran Gigi, Universitas Gadjah Mada \\ Jl. Denta No.1 Sekip Utara Yogyakarta
}

\begin{abstract}
The success of dental implant insertion is oseointegration namely a direct connection between implant body (substructure) and bone tissue without any intervening soft tissue. Osteoclast plays an important role in bone resorption which interrupts oseointegration process. The purpose of study was to investigate the effect of risedronate (Ris) as a potential drug for inhibiting of osteoclast proliferation. Thirtysix Wistar rats aged 9-10 weeks, weighed 280-300 grams were divided into 4 groups of 9 each. Each group was divided into 3 subgroups $(\mathrm{n}=3)$. Group I as a control was injected by $0.05 \mathrm{~mL} 0.9 \%$ $\mathrm{NaCL}$ solution meanwhile group II,III, and IV were injected by $0.05 \mathrm{~mL} ; 250,500,1000 \mu \mathrm{mol} / \mathrm{L}$ concentration Ris in $0.9 \% \mathrm{NaCL}$ solution sequentially. All of subgroups received injection for 3 days interval in different duration day they were 14, 28 and 56 days. Statistical analysis were performed by using Kruskal-Wallis and U Mann-Whitney test to measure the significance of osteoclas amount between control and treatment group. The result showed that almost all of the groups were significantly different based on the dose $(\mathrm{p}<0.05)$ and not significantly different of the injection period $(\mathrm{p}>0.05)$.
\end{abstract}

Key words: risedronate, oseointegration, substructure, proliferation

\begin{abstract}
Abstrak
Keberhasilan gigi tiruan tanam, tergantung pada proses oseointegrasi, yaitu suatu hubungan langsung antara bagian implan gigi yang tertanam di dalam tulang rahang (substructure) dengan jaringan tulang disekitarnya tanpa ada pengaruh dari jaringan lunak yang lain. Osteoklas berperan penting dalam proses oseointegrasi karena sel tersebut mempunyai kemampuan untuk meresorpsi tulang. Tujuan penelitian ini untuk mengetahui pengaruh sediaan farmasi Risedronate (Ris) yang mempunyai kemampuan untuk mencegah proliferasi osteoklas. Tiga puluh enam tikus Wistar berumur 9-10 minggu dengan berat antara 280-300 gram dibagi menjadi 4 kelompok $(n=9)$, setiap kelompok dibagi lagi menjadi 3 subkelompok $(\mathrm{n}=3)$. Kelompok I sebagai kontrol dengan perlakuan injeksi $0,05 \mathrm{~mL}$ cairan $0,9 \% \mathrm{NaCL}$ sementara kelompok II, III, dan IV diinjeksi 0,05 mL sediaan Ris dengan konsentrasi 250, 500, dan $1000 \mu \mathrm{mol} / \mathrm{L}$ secara berurutan. Injeksi dilakukan setiap 3 hari sekali dengan lama waktu pemberian injeksi yang berbeda-beda, yaitu 14, 28, dan 56 hari. Analisis statistik menggunakan Uji Kruskal-Wallis dan U Mann-Whitney. Hasil penelitian menunjukkan terdapat perbedaan yang bermakna pada kelompok dosis Ris $(\mathrm{p}<0,05)$ dan tidak signifikan pada kelompok hari amatan $(\mathrm{p}>0,05)$.
\end{abstract}

Kata kunci: risedronate, oseointegrasi, substructure, proliferasi

\section{PENDAHULUAN}

Sekitar $69 \%$ orang dewasa telah kehilangan se- tidaknya satu gigi permanen dan permasalahan ini telah menjadi perhatian umat manusia di seluruh dunia sejak beberapa abad yang lalu, tidak terkecuali 
di Indonesia. Berbagai upaya telah dilakukan untuk mengatasi keadaan tersebut, salah satunya ialah dengan pemasangan implan gigi. ${ }^{1}$ Implan gigi kemudian menjadi sangat populer dikarenakan diketemukannya konsep oseointegrasi. ${ }^{2,3}$ Istilah oeseointegrasi pada ilmu implan gigi (dental implantology) dapat diartikan sebagai suatu proses perlekatan antara jaringan tulang dengan permukaan bagian implan gigi yang tertanam di dalam tulang rahang (substructure). Angka keberhasilan insersi implan gigi menunjukkan perkembangan yang signifikan. Data tentang keberhasilan pemasangan implan gigi mencapai 95,4\% setelah 5 tahun insersi dan $92,8 \%$ setelah 10 tahun insersi. ${ }^{4}$ Kegagalan yang terjadi di antaranya dikarenakan fenomena seluler dan molekuler pada proses oseointegrasi sebagian besar masih belum diketahui secara pasti. ${ }^{5-7}$

Kendala yang biasanya timbul pada proses oseointegrasi adalah adanya perlukaan tulang sebagi akibat dari prosedur insersi implan yang diikuti oleh munculnya sel osteoklas pada sekitar perlukaan tulang ditempat pertemuan antara jaringan tulang dengan substructure. Keadaan ini akan memacu terjadinya resorpsi tulang yang akan mengganggu proses oseointegrasi dikarenakan adanya hambatan regenerasi tulang pada sekitar daerah tersebut.

Dalam dunia farmakologi dikenal adanya risedronate (Ris) turunan dari bisphosphonate (BPs) suatu sediaan yang dapat mengatur metabolisme tulang. ${ }^{8}$ Ada 13 macam turunan BPs yang sering dipergunakan dalam kehidupan manusia terutama sebagai pengobatan penyakit tulang. Dari semua turunan tersebut Ris merupakan yang paling baik dikarenakan mempunyai kemampuan selektif dalam hal menghambat resorpsi tulang pada rentang dosis yang lebar. Perbedaan respons osteoklas yang ditimbulkan oleh Ris tergantung pada metode pemberian dan dosis Ris yang diberikan, dan sediaan ini telah banyak dipakai sebagai obat pada pasien osteoporosis dan osteoarthritis baik dengan pemberian secara injeksi maupun per oral $^{9}$

Osteoklas merupakan salah satu jenis sel di dalam tulang yang mempunyai kemampuan untuk dapat mengekspresikan enzim tartrate resistant acid phosphatase (TRAP) yang merupakan enzim metaloprotein dan termasuk golongan asam phospat. TRAP adalah produk bagi osteoklas dan merupakan penanda secara biokimia untuk mengenali adanya resorpsi tulang. ${ }^{10}$ Sel osteoklas diketahui secara pasti mempunyai kemampuan yang tinggi dalam mengekspresikan TRAP. ${ }^{11}$ Adanya aktivitas TRAP yang tinggi dapat dipakai sebagi petunjuk bahwa telah terjadi absorpsi tulang. Peranan Ris sebagai penghambat resorpsi tulang dapat dideteksi melalui enzim TRAP dengan pengamatan secara histokimia berdasarkan ekspresi osteoklas. Berkurangnya jumlah osteoklas berarti adanya penurunan produksi enzim TRAP dan ini merupakan penanda adanya penurunan metabolisme absorpsi tulang yang aktif. ${ }^{12,13}$

Teori yang mendasari mekanisme cara kerja Ris terhadap terjadinya proses regenerasi tulang dan oseointegrasi adalah sebagi berikut:

1. Ris dapat mengikat secara kuat terhadap mineral tulang kemudian melakukan penetrasi ke dalam osteoklas dan menstimulasi untuk terjadinya apoptosis pada osteoklas tersebut.

2. Tingkat seluler, secara invitro Ris dapat menaikkan biosintesis kolagen, pembentukan osteocalcin oleh sel-sel tulang dan proteoglycan oleh sel-sel kartilago, mencegah proliferasi, adesi dan memperpendek umur dari osteoklas. ${ }^{14-15}$

Penelitian ini diharapkan dapat memberi informasi yang bermanfaat mengenai pengaruh Ris terhadap ekspresi enzim TRAP melalui pengamatan penurunan jumlah osteoklas. Keadaan tersebut dapat dijadikan pertimbangan oleh para klinisi yang berkompeten dalam ilmu implan gigi untuk mendukung prognosis yang lebih baik terhadap insersi implan gigi dengan mewujudkan terjadinya proses oseointegrasi yang lebih cepat dan lebih luas, sehingga dapat segera dilakukan pemasangan protesa gigi dan ini berarti mempersingkat waktu keadaan pasien tanpa gigi (ompong).

\section{BAHAN DAN METODE}

Setelah selama 1 minggu menjalani adaptasi kandang, 36 ekor tikus Wistar jantan dengan umur 9-10 minggu dan berat badan rata-rata 280-300gr. dibagi menjadi 4 kelompok besar $(n=9)$ untuk perlakuan variabel dosis dan durasi injeksi. Kelompok I sebagai kelompok kontrol dengan injeksi $0,05 \mathrm{ml}$ $0,9 \% \mathrm{NaCL}, \mathrm{pH} 7,4$ sementara kelompok II, III, dan IV menerima perlakuan injeksi Ris sebanyak pada perlakuan kontrol sekitar substructure pada tempat kedudukan model implan terinsersi dengan kosentrasi 250,500 , dan $1000 \mu \mathrm{mol} / \mathrm{L}$ dalam larutan $0,9 \%$ $\mathrm{NaCL}, \mathrm{pH}$ 7,4 setiap 3 hari sekali selama 14, 28, dan 56 hari. Seluruh hewan coba dikorbankan sesuai dengan kelompok durasi pemberian Ris dengan metode trans cardial perfusion.

Prosedur histokimia dilakukan untuk pengamatan ekspresi enzim TRAP dengan menggunakan mikroskop cahaya perbesaran 40 kali yang dihubungkan dengan optilab untuk melakukan penghitungan sel osteoklas dengan menggunakan program image raster. Pengamatan subjek penelitian dilakukan berdasarkan potongan menurut sumbu panjang substructure menjadi 2 segmen yaitu segmen kanan dan 
kiri, setiap segmen dibagi menjadi 2 lapang pandang dengan demikian setiap sampel mempunyai 4 lapang pandang.
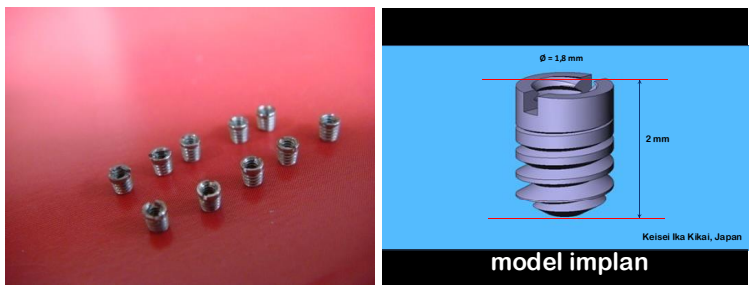

Gambar 1. Model implan; panjang $2 \mathrm{~mm}$, diameter 1,8 $\mathrm{mm}$

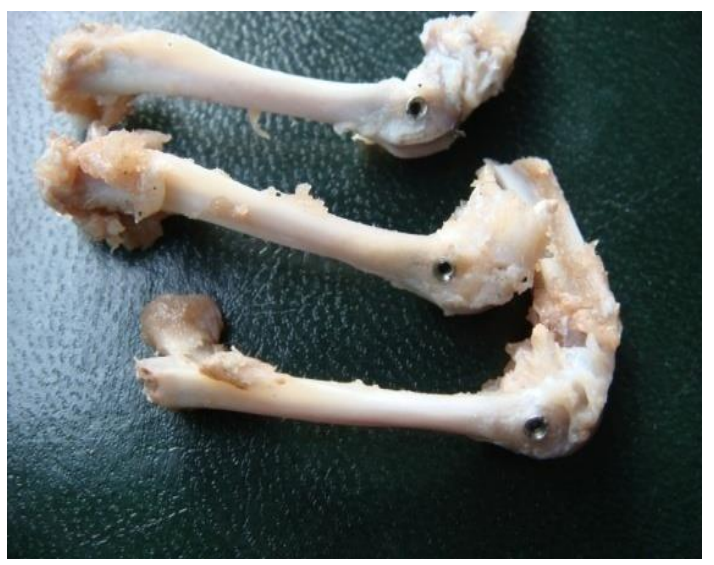

Gambar 2. Kedudukan model implan pad epicondylus lateralis femoris tikus Wistar

\section{HASIL}

Hasil pengamatan secara histologi dengan menggunakan optilab dan perhitungan osteoklas berdasarkan program image raster untuk 4 lapang pandang setiap subjek penelitian, menunjukkan rerata dan simpangan baku ekspresi osteoklas berdasarkan konsentrasi dosis dan hari amatan (Tabel 1).

Tabel 1. Rerata dan simpangan baku ekspresi osteoklas berdasarkan kelompok dosis Ris dan hari perlakuan

\begin{tabular}{ccccc}
\hline & \multicolumn{4}{c}{ Larutan injeksi } \\
\cline { 2 - 5 } Kelompok & $0,9 \%$ & \multicolumn{4}{c}{ Dosis Ris } \\
\cline { 3 - 5 } hari & $\mathrm{NaCL}$ & 250 & 500 & 1000 \\
& $(\mathrm{kontrol})$ & $\begin{array}{c}\varepsilon \mathrm{mol} / \mathrm{L} \\
(\mathrm{dosis} A)\end{array}$ & $\begin{array}{c}\varepsilon \mathrm{dos} / \mathrm{L} \\
(\mathrm{dosis} \mathrm{B})\end{array}$ & $\begin{array}{c}\varepsilon \mathrm{mol} / \mathrm{L} \\
(\text { dosis C) }\end{array}$ \\
\hline Hari ke-14 & $0,666 \pm$ & $1,083 \pm$ & $0,416 \pm$ & $0,333 \pm$ \\
& 0,408 & 0,584 & 0.491 & 0.408 \\
Hari ke-14 & $1,583 \pm$ & $0,666 \pm$ & $0,333 \pm$ & $0,250 \pm$ \\
& 1,068 & 0,408 & 0,408 & 0,418 \\
Hari ke-14 & $0,916 \pm$ & $0,750 \pm$ & $0,583 \pm$ & $0,166 \pm$ \\
& 0,735 & 0.689 & 0,584 & 0,258 \\
\hline
\end{tabular}

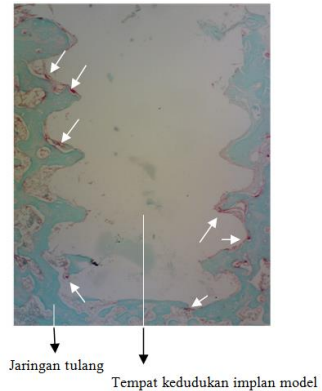

Gambar 3. Potongan menurut sumbu panjang subyek penelitian. Osteoklas tampak berupa sel bentuk tidak beraturan dan berwarna merah (tanda panah)

Pengamatan secara histokimia diperoleh hasil sebagai berikut; untuk kelompok I (kontrol) masih banyak osteoklas yang tersebar baik pada daerah tengah penulangan maupun daerah pertemuan antara substructure dengan tulang disekitarnya (Gambar.4a). Kelompok II sebaran osteoklas mulai berkurang pada daerah tengah penulangan tetapi masih banyak terlihat daerah-daerah yang kosong (belum ada penulangan) pada daerah tersebut (Gambar.4b). Kelompok perlakuan III, proses penulangan mulai terjadi dan hanya terlihat beberapa osteoklas pada tempat pertemuan antara substructure dengan tulang disekitarnya (Gambar.4c). Kelompok IV menunjukkan ada perbedaan yang sangat signifikan dengan kelompok-kelompok sebelumnya. Ekspresi osteoklas mulai jauh berkurang bahkan sampai tidak terdeteksi dan hampir sudah terjadi penulangan yang sempurna baik pada daerah pertemuan antara substructure dengan tulang disekitarnya maupun pada daerah penulangan bagian tengah (Gambar.4d).
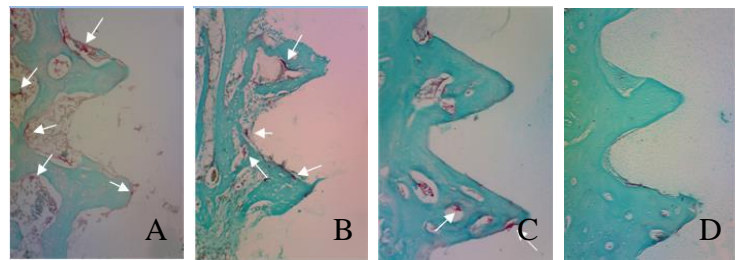

Gambar 4. Osteoklas adalah sel-sel yang berwarna merah (tanda $\mathrm{a}=14,28$, dan 56 hari injeksi larutan $0,05 \mathrm{~mL}$ (kontrol), $\mathrm{b}=14,28$, dan 56 hari injeksi $0,05 \mathrm{~mL}$ dosis $\mathrm{A}, \mathrm{c}=14,28$, dan 56 hari injeksi $0,05 \mathrm{~mL}$ dosis $\mathrm{B}, \mathrm{d}=14,28$, dan 56 hari injeksi $0,05 \mathrm{~mL}$ dosisC

Hasil uji Krukal-Wallis menunjukkan ada perbedaan yang signifían dengan nilai $p=0,022(p<$ 0,05), membuktikan bahwa konsentrasi pemberian bisphosphonate jenis Ris berpengaruh terhadap pe- 
nurunan proliferasi osteoklas pada daerah pertemuan antara tulang dengan substructure berdasarkan dosis Ris yang diberikan. Sementara berdasarkan hari amatan diperoleh nilai $p=0,813(p>0,05)$ berarti tdak terdapat perbedaan yang bermakna antar kelompok hari amatan terhadap penurunan proliferasi osteoklas sehubungan dengan perlakuan injeksi Ris.

Hasil uji U Mann-Whithney diperoleh hasil bahwa seluruh masing-masing kelompok perlakuan (kontrol dan dosis Ris) terdapat perbedaan yang bermakna $(\mathrm{p}<0,05)$ terhadap penurunan proliferasi osteoklas kecuali kelompok kontrol terhadap dosis A (p>0,05). (Tabel 2)

Tabel 2. Hasil uji U Mann-Whithney ekspresi mosteoklas berdasarkan dosis Ris

\begin{tabular}{lcccc}
\hline Dosis obat & \multirow{2}{*}{ Kontrol } & $\begin{array}{c}\text { Dosis } \\
\text { A }\end{array}$ & $\begin{array}{c}\text { Dosis } \\
\text { B }\end{array}$ & $\begin{array}{c}\text { Dosis } \\
\text { C }\end{array}$ \\
\hline Kontrol & & 0,504 & $0,019^{*}$ & $0,001^{*}$ \\
Dosis A & & & $0,038^{*}$ & $0,001^{*}$ \\
Dosis B & & & & $0,017^{*}$ \\
Dosis C & & & & \\
\hline
\end{tabular}

*bermakna $(p$-value $<0,05)$

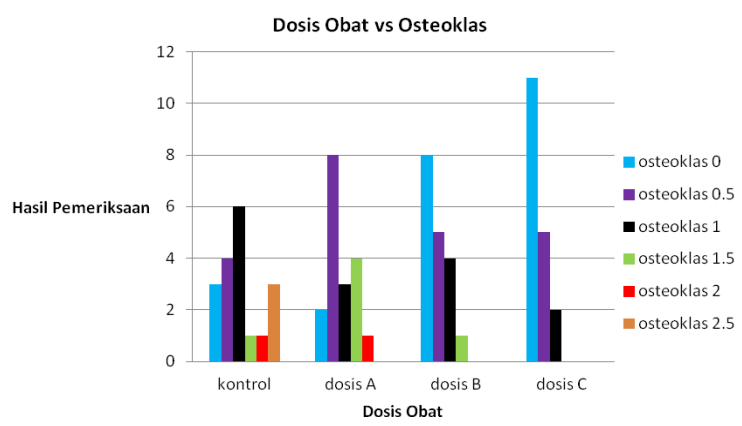

Gambar 5. Ekspresi osteoklas berdasarkan konsentarsi dosis obat dan hasil pemeriksaan

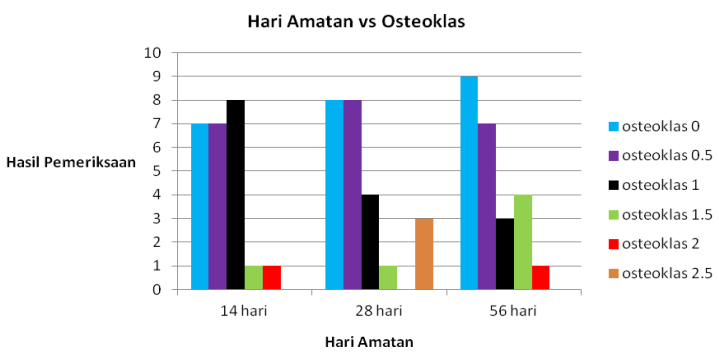

Gambar 6. Ekspresi osteoklas berdasarkan hari amatan dan hasil pemeriksaan

\section{PEMBAHASAN}

Hasil uji U Mann-Whitney (Tabel 2) menunjukkan bahwa terdapat perbedaan yang bermakna antara kelompok kontrol dan kelompok perlakuan terhadap penurunan ekspresi osteoklas yang dipengaruhi oleh besarnya konsentrasi dosis yang diberikan (Gambar.5). Penurunan jumlah osteoklas pada kelompok perlakuan terhadap kelompok kontrol diakibatkan oleh karena adanya aktifitas Ris yang berfungsi untuk mendegradasi osteoklas pada daerah perlukaan tulang sekitar substructure. Risedronate adalah turunan dari BPs dan merupakan 1 diantara 13 turunan BPs yang paling berpotensi dalam menghambat resorpsi tulang (potent blocker of bone resorption). Ris secara efektif dapat memperlambat proses kerusakan tulang dengan cara menghambat resorpsi tulang oleh osteoklas.

Mekanisme kerja Ris pada tingkat seluler, secara invitro dapat menaikan biosintesis kolagen, pembentukan osteocalcin oleh sel-sel tulang dan proteoglycan oleh sel-sel kartilago. Selain itu juga mencegah proliferasi dan adesi osteoklas, memperpendek umur osteoklas dan menghambat aktivitas osteoklas. ${ }^{9,13}$

Penurunan ekspresi osteoklas dimulai pada dosis 500 dan $1000 \mu \mathrm{mol} / \mathrm{L}$ sementara dosisi $250 \mu \mathrm{mol} / \mathrm{L}$ belum mampu umtuk menurunkan proliferasi osteoklas. Keadaan ini sesuai dengan pernyataan yang mengatakan bahwa perbedaan respons osteoklas terhadap hambatan proliferasinya oleh karena Ris tergantung pada metode pemberian dan dosis yang diberikan. ${ }^{9,10}$

Berdasarkan hasil uji Kruskal-Wallis diperoleh adanya perbedaan ekspresi osteoklas yang tidak signifikan antara kelompok hari amatan terhadap proliferasi osteoklas. Keadaan ini terjadi karena Ris akan melakukan tahapan biosintesis pada proteinprotein yang bertanggung jawab terhadap keutuhan sitoskeletal sel osteoklas hanya berdasarkan konsentrasi dosis yang diberikan tidak dan berdasarkan durasi pemberiannya. Berarti pada setiap kelompok kontrol maupun kelompok dosis Ris bekerja sesuai konsentrasinya dan tidak terpengaruhn oleh durasi hari pemberian Ris (Gambar.6). Ekspresi osteoklas berdasarkan konsentrasi dosis perkelompok perlakuan ini dapat digunakan sebagai indikator bahwa sedang terjadi penurunan volume enzim TRAP pada daerah sekitar substructure (Tabel 1). Hal ini terbukti setelah dilakukan uji U Mann-Whitney untuk melihat signifikansi perbedaan antara masing-masing kelompok dosis Ris menunjukkan bahwa penurunan proliferasi osteoklas berdasarkan konsentrasi dosis yang diberikan $(\mathrm{p}<0,05)$. Sebagai kesimpulan, risedronate (Ris) dapat menurunkan produksi enzim tartrate resistant acid phosphatase (TRAP) berdasarkan ekspresi osteoklas pada daerah sekitar substructure hanya berdasarkan dosis yang diberikan. Akibat penurunan enzim ini proliferasi osteoklas menurun yang akan berpengaruh terjadi- 
nya regenerasi tulang lebih cepat dan lebih luas sehingga fenomena tersebut akan mendukung percepatan dan perluasan proses oseointegrasi dengan demikian pemasangan bangunan protesa gigi pada implant abutment/ superstruture dapat segera dilakukan.

\section{Daftar Pustaka}

1. Anonymous. Memeriksa laporan pasar seluruh dunia nanoteknologi implan gigi. http://www. azonano.com/news.aspx?newsID=11402\&lang=id (1 Januari 2011).

2. Dimitriou R, Babis GC. Biomaterial osseointegration Enhancement with biophysical stimulition. J Musculoskelet Neuronal Interact 2007; 7(3): 253-65.

3. Ustun Y, Erdogan O, Kurkcu M, Akova T, Damlar I. Effect of Low-Intensity Pulsed U trasound on Dental Implant Osseointegration: A Preliminary Report. European J Dentistry 2008; 2: 254-62.

4. Ching Yu T. Using mini dental implant to improve the stability of an existing mandibular complete denture in patient with severe ridge resorption. $\mathbf{J}$ Prosteth Dent 2012; 1(2): 48-52.

5. Lang NP, Berglundh T, Lisa J, Mayfield H, Pjetursson BE, Solvi GE, et al. Consensus statements and recommened clinical procedures regarding implant survival and complications. Proccedings of the third ITI concensus conference 2004.

6. Xu B, Zhang J, Brewer E, Tul Q, Yu L, Tang J, et al. Osterix Enhances BMSC-asociated Osseointegration of Implants. J Dent Res 2009; 88(11): 1003-7.

7. Omar O. Mechanism of osseointegration: experimental studies on erlay celluler and molecular events in vivo. University dissertation from University of Gonthenburg 2010.

8. Masud T, McClung M, Geusens P. Reducing hip fracture risk eith risedronate in eldelery women with established osteoporosis. Clinical Interventions in Aging 2009; 4: 445-49.

9. Iwamoto J, Takeda T, Sato Y, Matsumoto H. Effects of residronate on osteoarthritis of the knee. Yonsei Med J 2010; 51(2): 164-70.

10. Siris ES, Simon JA, Barton IP, McClung MR, Grauer, A. Effects of residronate on fracture risk in postmenopausal women with osteopenia. Osteoporos Int 2008; 19: 681-86.

11. Perez-Amodio S, Vogels IMC, Schoenmaker T, Jansen DC, Alatalo SL, Halleen JM, et al. Endogenous expression and endocytosis of tartrateresitant acid phosphatase (TRAP) by osteoblast-like. Bone 2005; 36(6): 1065-77.

12. Honig A, Rieger L, Kaap M, Krockenberger M, Eck $\mathrm{M}$, Dietl J, et al. Increased tartrate-resistant acid phosphatase (TRAP) expression in maligna breast, ovarian and melanoma tissue: an investigational study. BMC Cancer 2006; 199.

13. Russell RG, Xia Z, Dunford JE, Oppermann U, Kwaasi A, Hulley PA, et al. Bisphosphonate: an update on mechanisms of action and how these relate to clinical afficacy. Ann NY Acad Sci 2007; 1117: 209-57.

14. Woo SB, Hellstein JW, Kalmar JR. Bisphosphonate and osteonecrosis of the jaw. Ann Intern Med 2006; 16(10): 753-61.

15. Maria TV, Sandro G, Luca D, Mikro Z, Francesco $\mathrm{B}$, Stefania S, et al. The effect of risedronate on osteogenic lineage is mediated by cyclooxygenase- 2 gene upregulation. J Athritis Res Ther. 12(4): 1-14. 